\title{
Analysis of Ukrainian National Legislation and European Union Standards on Animal Use for Scientific Purposes: Directions and Prospects
}

\author{
Anna Liubchych*1, Hasrat Arjjumend ${ }^{2}$, Panfilova Daria ${ }^{3}$, Olena Savchuk ${ }^{4}$ \\ ${ }^{1,3}$ Scientific and Research Institute of Providing Legal Framework for the Innovative Development, \\ National Academy of Law Sciences of Ukraine, Kharkiv, Ukraine. \\ ${ }^{2}$ CISDL, McGill University Faculty of Law, Montreal (Quebec) H3A 1X1, Canada \\ ${ }^{2}$ The Grassroots Institute, Montreal (Quebec) H3N 1R5, Canada \\ ${ }^{4}$ Department of Environmental Law, Yaroslav Mudryi National Law University of Ukraine, Kharkiv, Ukraine \\ *Corresponding author (E-mail: anna.n.l@ukr.net) | ORCID: 0000-0002-6492-4179
}

How to cite this paper: Liubchych, A., Arjjumend, H., Daria, P. and Savchuk, O. (2020). Analysis of Ukrainian National Legislation and European Union Standards on Animal Use for Scientific Purposes: Directions and Prospects. Grassroots Journal of Natural Resources, 3(3): 46-55. Doi: https://doi.org/10.33002/nr2581.6853.03034

Received: 27 July 2020

Reviewed: 12 August 2020

Provisionally Accepted: 25 August 2020

Revised: 01 September 2020

Finally Accepted: 11 September 2020

Published: 15 September 2020

Copyright (C) 2020 by author(s)

This work is licensed under the Creative Commons Attribution International License (CC BY 4.0).

http://creativecommons.org/licenses/by/4.0/
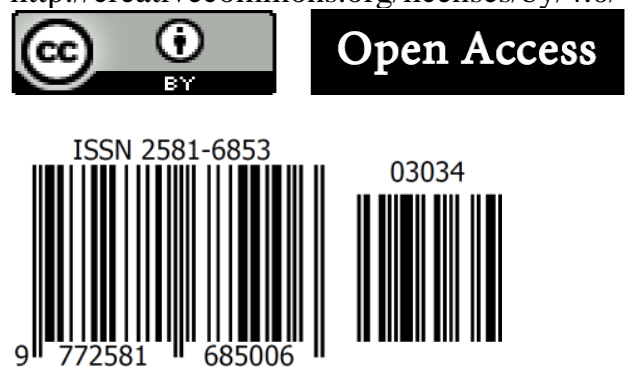

\begin{abstract}
The tasks of analyzing the processes underneath the integration of national legislation of Ukraine conforming with that of the European Union are critical for strengthening the State in quest of gaining membership in the European Union with the achievement of the strategic goals. This analytical article aims: 1) to unveil the genesis of the legal reform in the field of animal protection from ill-treatment and the use of animals for scientific purposes in Ukraine, 2) to analyze and summarize the features of regulations pertaining to the protection of animals from abuse within the EU, and 3) to outline further directions in reforming the domestic legislation of Ukraine concerning animal protection against ill-treatment and use of animals for scientific purposes in the context of European integration. Ukraine is gradually intensifying the process of reforming domestic legislation concerning cruelty to animals and use of animals for scientific purposes. The Verkhovna Rada (the Supreme Council) of Ukraine adopted Draft Law № 2351 of 30.10.2019, which still requires reformation to solve the highlighted problems. Some solutions are recommended for the Government of Ukraine.
\end{abstract}

Keywords

Cruelty to animals; EU legislation; Ukrainian Legal reform 
Doi: https://doi.org/10.33002/nr2581.6853.03034

\section{Introduction}

Despite the preventive measures taken by the world community to overcome negative consequences of human activities, year by year it is becoming harder to protect and preserve wildlife, particularly in the cross-border contexts. Moreover, extinction of many species is becoming a serious problem globally. There are difficulties in creating effective mechanism of global protection to the wildlife, and such difficulties are exacerbated by the global demands to preserve the ecosystems. A diversity among international standards and national legal frameworks add further challenges to wildlife protection and preservation. These challenges give rise to a special importance to be given to environmental legal research, which should be carried out addressing the dimensions of national law-making process and integrating the foreign experiences in regulating the wildlife protection and extending international cooperation.

Amid rapidly growing challenges of reforms and changing European geopolitical realm, development of Ukrainian state, undoubtedly, requires a strategic and careful planning. Both national and regional strategic plans should be associated with improved implementation of European standards and strong domestic legal apparatus. Under such conditions, of particular importance is the cooperation between legislators and scientists aiming at accomplishing highest quality legislation and its effective enforcement. In its pursuit, analysis of the process of integration of national legislation of Ukraine with European Union legislation becomes particularly important. Such an exercise appears essential towards strengthening the State-building and achieving strategic planning in the specific context of Ukraine's membership of the European Union.

Recently, special attention has been paid to issues related to the protection of wildlife and the use of animals in scientific experiments (NHMRC, 2013) and economic activities. It is worth emphasizing that, in Ukraine, this issue is given considerable attention; however, at the same time, the legal regulation does not fully meet international standards and requirements. An EU Directive 2010/63/EU ${ }^{1}$ on the Protection of Animals Used for Scientific Purposes is included in the Ukraine's Action Plan for the implementation of the Association Agreement between Ukraine and the European Union, the European Atomic Energy Community and its Member States. ${ }^{2}$ This Directive is not yet ratified and incorporated in the national legal framework of Ukraine. Notably, the European Commission has reported that the said Directive 2010/63/EU caused reduction in suffering of the animals being used for research apart from the reduced number of animals being used. ${ }^{3}$ It should be noted that European Community legislation sets high standards for the maintenance and care of animals. The legislation also encourages the use of testing methods that cause minimum pain to animals and involve a minimum number of animals. Such positive practices deserve attention of legal research community.

\footnotetext{
${ }^{1}$ On the protection of animals used for scientific purposes: Directive 2010/63/EU of the European Parliament and of the Council of 22 September 2010. https://eurlex.europa.eu/LexUriServ/LexUriServ.do?uri=OJ:L:2010:276:0033:0079:EN:PDF

${ }^{2}$ On the implementation of the Association Agreement between Ukraine, of the one part, and the European Union, the European Atomic Energy Community and their Member States, of the other part: order of Cabinet Ministry of Ukraine of 25.10 .2017 no. 1106. https://zakon.rada.gov.ua/laws/show/1106-2017-\%D0\%BF\#n13

${ }^{3}$ Commission adopts detailed reports on the use of animals in science in the EU, 05.02.2020. https://ec.europa.eu/info/files/commission-adopts-detailed-reports-use-of-animals-in-science-in-EU en
} 
The purpose of this legal research article is to conduct a comprehensive comparative study of the legislation of the European Union and the Ukraine dealing with the protection of fauna. These laws regulate the protection of animals from ill-treatment and use for scientific purposes. This research aims at finding the efficient practices of enforcement of laws in Ukraine. The objectives of the research include: 1) to reveal the genesis of legal reform in context of animal protection from illtreatment and use for scientific purposes in Ukraine; 2) to analyze the peculiarities of regulations protecting animals against ill-treatment within the EU system; and 3) to determine the future direction of the legal reform of Ukraine inferring to European integration concerning protection of animals from ill-treatment and use for scientific purposes.

Over the last decade, issues of implementing and integrating European standards concerning the protection of fauna have received considerable attention by the environmental law schools. However, in modern Ukrainian jurisprudence, there is a vacuum of comprehensive scientific comparative studies addressing legislation of Ukraine and the European Union in the context of the cruelty to animals and use of animals in scientific experiments.

\section{Methodology}

The theoretical and methodological basis of the legal research justifies the chosen approaches, the principles employed, and analysis conducted. The research methods included dialectical, systemic, structural-functional and informational approaches. Analytical approaches were based on the terminological principle and the principles of systemic integrity, hierarchy, structure, etc.

In this study, historical legal and comparative legal methods are used to understand the origins of regulations addressing protection of animals globally and domestically. These methods are useful to know specific stages of development of the legislation. The comparative legal method is applied for comparative study of legal rules providing for the use of animals in scientific and economic activities while ensuring their protection from cruel treatment. Normative-dogmatic method is applied to discover a number of normative-legal aspects of legislation in Ukraine and the European Union. Other methods include terminological analysis and operationalization of concepts, which are used in the process of establishing the concepts such as "protection of animals from cruelty", "cruelty to animals", "animal laboratory", and "experimental animal". With the help of said methods an imperfection in the terminology apparatus of environmental legislation of Ukraine is revealed. A method of classification is employed in analysing the main stages of legal framework development for the protection of animals from ill-treatment in Ukraine. Lastly, a method of legal modeling is employed to identify the potential prospects for further reform in environmental legislation of Ukraine with reference to international cooperation. Using such a combination of methods has an advantage in understanding problems better and in analyzing complex issues reasonably.

\section{Discussions}

In contemporary world, ability of a State to carry out reforms is one of the indicators of its development, as it can determine the pace and degree of improvement of economic, political, social spheres of public life. The influence of globalization should be acknowledged in the processes of modernization, transformations, reforms and alike. Equally, the environmental protection, rational use of natural resources and environmental sustainability are the keys to the existence of not only 
the people and nation, but also the planet Earth. Such tenets should be the priorities of public policy. Notably, leading countries emphasize on harmonized legal, regulatory and organizational frameworks that meet the requirements of their respective national and regional environmental security and sustainability (Lozo, 2018).

During 1970s, several international legal instruments (regional and global treaties and agreements) giving protection to certain species of animals came into existence (Bulikina, 2019). To provide protection to the animals from ill-treatment and use for scientific purposes, European Union created a significant number of legal frameworks. These frameworks guided the existing relationships among EU member countries, and increased liability for wrongful acts and standardized doctrinal approaches. The driving force for Ukraine to adopt legislative reforms is the conformation to the international treaties, such as the European Convention for the Protection of Animals during International Transport (1968), European Convention for the Protection of Animals kept for Farming (1976), European Convention on the Protection of Animals for Slaughter (1979), European Convention for the Protection of Vertebrate Animals used for Experimental and Other Scientific Purposes ${ }^{4}$ (1986), European Convention for the Protection of Pet Animals (1987). In Ukraine, the legal reform innovations began on 21 February 2006 when Law of Ukraine № 3447IV "On Protection of Animals from Brutal Treatment" was passed, which, unfortunately, was fragmented reflection of the European standards. However, this same law is amended with the eleventh edition. But, unfortunately, no alterations are made from 2017 to 2020 in the law, despite the rapid changes in social relations, the environment and the animal world.

The Resolution No. 162 of 16.11.2011 vide № 1402 of the Cabinet of Ministers of Ukraine “On Approval of the Rules for Transportation of Animals" established uniform requirements for the transportation of wild, domestic and farm animals. It also consolidated the processes of improving the legislation in the context of European integration. Subsequently, adopted rules have ensured humane treatment to the animals during their transportation and have become the primary effective mechanism for preventing cases of cruel treatment.

Nevertheless, international legal framework on animal welfare is based on the principles of animal welfare and protection (Voelkl et al., 2020). The science explains two distinguished concepts explicitly. Welfare means keeping the animals in suitable conditions where they can be largely free from disease, able to effectively cope with weather conditions, and exhibit the diversity of species. The protection of animals in science is chiefly understood as the prevention from cruel treatment. However, in the regulatory frameworks of both Ukraine and the Commonwealth of Independent States (CIS), such definition is missing. Although the Law of Ukraine of 21.02.2006 № 3447-IV "On Protection of Animals from Cruel Treatment" actively uses this concept, yet it does not explain it properly. It only cites general rules for the treatment of animals that exclude cruelty (Bulikina, 2019).

Between 2006 and 2014, the Ukrainian environmental legislation was characterized by complex and contradictory processes, remained quite imperfect, developed chaotically and depended on the erstwhile political situations. However, international cooperation, bilateral contractual frameworks and assimilation of foreign experiences can qualitatively transform the environmental legislation

\footnotetext{
${ }^{4}$ European convention for the protection of vertebrate animals used for experimental and other scientific purposes. Council of Europe, Strasbourg, 1986. 53 p.
} 
of Ukraine, and identify new directions for legal reform. This is further strengthened by the Association Agreement between Ukraine and the European Union, the European Atomic Energy Community and their Member States ${ }^{5}$, which was ratified in 2014 and entered into force in 2017. This is considered to be most significant document in the history of independent Ukraine both in terms of the scale of relations with the European Union and the nature of reforms carried out by State of Ukraine (Hetman, 2017). In accordance with the requirements of Article 64 and Annex V of the Agreement, Ukraine should alter its animal protection legislation to conform the EU legislation. These international legal obligations concerning animal protection are also enshrined in Annex IV-B ("Standards for the maintenance and treatment of animals") of Chapter 4 of the Association Agreement.

In 2017, Ukraine joined the European Convention for the Protection of Vertebrate Animals used for Scientific Purposes (although the document of this Convention was adopted distantly in 1986). Surprisingly, no action to implement the international instrument has yet taken place. Scientists hint that a possible reason of showing no urgency to the legislative changes is the lack of common understanding for the improvement of regulation concerning animal welfare. It would have suggested a consistent solution for practical problems. So, the said lack of legislative reform causes the inconsistency in legal acts and, as a consequence, lack of knowledge on protection of animals (Kalmykov, 2013). In addition, conservation of rare and threatened species of wild animals in Ukraine is important not only for the country but also for the European and international community.

As a result of consumer lobbying across the EU region over the last three decades, there have been rapid changes in testing of cosmetics and personal care products. ${ }^{6}$ In 1993, a ban was introduced on the testing of cosmetics on animals by virtue of Sixth Amendment to the Directive 76/768 / EEC of 27 July 1976 (the EU Cosmetics Directive). Considering no implementation of this ban for so long, the Seventh Amendment was adopted in 2003 in the said EU Cosmetics Directive, which provided for a phased ban on the testing on animals of cosmetic products and their ingredients sold in the EU. This ban finally came into full force in 2013, 10 years after public opinion successfully advocated in support of the original ban. Additionally, instructions of treating the animals during the experiments were, inter alia, explained in the Regulation of the European Parliament and the Council of the European Union (1223/2009 EU of 30.11.2009) on Cosmetics.

Nevertheless, the most prominent document for the purpose of this study is the EU Directive 2010/63/EU on the Protection of Animals used for Scientific Purposes. Various member States of the EU amended their respective national legislation to conform the Directive, but their magnitude differed significantly. In fact, emerging new requirements for classifying the severity of the mistreatment of animals, and retrospective assessment and timeliness of decision-making on granting permission for research using animals have led to reforming the national legislations. In this reference, most member States of EU reported that they have made significant changes in relevant legislation complying with the requisite scope, placement, care, methods of killing, and

\footnotetext{
5 Угода про асоціацію між Україною, з однієї сторони, та Європейським Союзом, Європейським співтовариством з атомної енергії і їхніми державами-членами, з іншої сторони: Закон України від 16.09.2014 p. № 1678-VII. Відомості Верховної Ради Украӥни. 2014. № 40. Ст. 2021. Order of the Cabinet Ministry of Ukraine of 25.10.2017 no. 1106. URL: https://zakon.rada.gov.ua/laws/show/1106-2017-\%D0\%BF\#n13 ${ }^{6}$ https://www.cosmeticsdesign-europe.com/Article/2020/06/08/ECHA-animal-testing-alternatives-report-forREACH-regulation-2020
} 
procedure of inspections (Lindl et al., 2012). This indicates that most of the member States are making determined efforts to comply with the EU Directive 2010/63/EU. Even though the experience of reforming legislations is still at nascent stage, in particular for those member States that transformed their laws slowly, a higher degree of efficiency is observed in the approaches of treating the animals.

The guidelines regulating the use of animals in research point out that such usage of animals is a privilege granted to the research community with the objective of promoting science, provided that the use of animals is necessary and consistent with the principles and procedures of protecting the animals. Notably, the use of animals in scientific research is generally accepted based on the presumption of "harm-benefit analysis" (HBA). The EU Directive 2010/63/EU stipulates that use of a particular kind of animal in scientific research can be possible only after the body responsible for the review of animal usage in research has provided a detailed and reasoned harm and benefit analysis (HBA) with the recommendation that the project complies with legislation, international standards and legal requirements. The procedure and process of conducting HBA is questioned, however. Some scientists argue that the indicators and algorithms that are used for carrying out HBA and the review process remain poorly defined or missing, while elsewhere HBA is not legalized nationally (Sandoe et al., 2015).

Further insights of HBA need to be highlighted here to establish its critical role in accomplishing scientific research using animals. HBA is based on ethical principles that guide scientific research on animals. In the EU region, the member States have the obligation to minimize enforcement of HBA before using animals in scientific research activities. Scientists consider HBA essential because the use of animals in research raises ethical issues as the harm to animals and benefits to humanity are involved in such matters (Bout et al., 2014). Experiments using animals provide critical knowledge, which is otherwise impossible to obtain by employing alternative methods. Hence, use of certain species of animals is inevitable for benefiting humans. However, because the experiments on animals are essential and important, it does not justify the use of animals without fulfilling ethical and moral prerequisites. Therefore, HBA must be conducted as an essential prerequisite when using the animals for scientific experiments.

The historical success of the experiments conducted on animals was insufficient to justify the continued use of animals, simply because science is constantly evolving with alternative methods available today. This justification cannot reasonably be applied as universal law or as an instrument (Olsson et al., 2015). The understanding of the principles of HBA vary within different States of the EU, and the information about HBA could not become desirably transparent. Fortunately, a Regulation (EC) 2019/101014 on Open Access was brought in June 2019 that significantly improved the transparency in the matters of using animals for scientific experiments. Moreover, the European Commission identified the priority areas of information flow to facilitate the implementation of the provisions of the Directive 2010/63/EU, guidance documents, etc., which are available in 23 languages of the European Union.

Undeniably, testing on animals has not slowed down compared to previous years. Interestingly, when the EU has progressive laws on the protection of animals, the United States does not formally recognize animals as sensitive beings. Hence, US is not reported to have developed a federal or State policy. Compared to the EU region, the United States of America has poorly developed laws on animal protection, as evidenced by the Animal Protection Index (API). In this context, the EU's 
experience appears to be more progressive and appropriate to be adopted. Here, Animal Protection Index needs to be explained. It is a ranking of 50 countries based on assessment of their legislation and political commitment for the protection of animals. ${ }^{7}$ In Ukraine, despite a legislation on the use of animals in science and its implementation, including fragmented understanding of the 3 Rs principles (replacement, reduction, refinement), animal welfare is not yet recognized as an important principle of building relevant relationships. A society caring for animals cannot be achieved without effective regulations. General rules, mechanisms and guidelines that combat cruelty to animals do exist in Ukraine; however, so far no enforcement mechanism under the legislation exists to protect animals used in laboratory for scientific research. To score better in the Animal Protection Index, the Government of Ukraine proposed to establish an Ethics Committee that would be responsible for examining the applications for seeking use of animals in scientific research ${ }^{8}$. Such Ethics Committee would be able to suspend or cancel the registration of establishments that fail to meet the criteria of animal welfare. Animals used for research should be provided with shelter, care, food and water to support animals' physiological and behavioural needs. A staff member in the laboratory, preferably a veterinarian, must take full care and protection of the animals to be used or being used for scientific experiments.

Considering above, it is worth highlighting that Ukraine has advanced the process of reforming its national legislation addressing cruelty to animals and the use of animals for scientific purposes. In the light of a growing number of legislative initiatives, a bill addressing protection of animals being used for scientific research was adopted by Verkhovna Rada of Ukraine on February 5, 2020. It is a draft law to amend certain legislative acts of Ukraine (concerning the implementation of the provisions of certain international agreements and EU directives in the field of protection of flora and fauna). The Bill having № 2351 was registered on October 30, 2019 (hereinafter known as the Draft Law № 2351 of 30.10 .2019$)^{9}$. In the subsequent paragraphs, an analysis of the contents of this Draft Law is presented.

The adopted Bill contains proposals to develop an environmental law conforming the European standards related to protection of fauna and flora. In particular, this Bill promotes the implementation of international legal obligations of Ukraine under the Association Agreement between Ukraine, on the one hand, and the European Union, the European Atomic Energy Community and its Member States, on the other hand ${ }^{10}$. Effective implementation of such legislative novelty will be a significant step forward in a bid to adopt positive European practices. However, the Draft Law № 2351 of 30.10.2019, despite its adoption, still needs to be finalized after desired changes in order to align its provisions with the Law of Ukraine № 0897 of 29.08.2019 on amendments to laws governing relations with nature. ${ }^{11}$ Attention should be paid to the fact that

\footnotetext{
${ }^{7}$ Animal Protection Index. URL: https://api.worldanimalprotection.org/

${ }^{8}$ Ukraine. Protecting animals used in scientific research. URL: https://api.worldanimalprotection.org/country/ukraine

${ }^{9}$ Про внесення змін до деяких законодавчих актів України (щодо імплементації положень деяких міжнародних угод та директив СС у сфері охорони тваринного та рослинного світу): проєкт Закону України від 30.10.2019 р. № 2351. Офіційний сайт Верховної Ради України. http://w1.c1.rada.gov.ua/pls/zweb2/webproc4_1?pf3511=67235

10 Угода про асоціацію між Україною, з однієї сторони, та Європейським Союзом, Європейським співтовариством з атомної енергії і їхніми державами-членами, з іншої сторони: Закон України від 16.09.2014 р. № 1678-VII. Відомості Верховної Ради України. 2014. № 40. Ст. 2021.

${ }^{11}$ Проект Закону про внесення змін до деяких законів України, які регулюють відносини, пов'язані 3 одержанням документів дозвільного характеру від 29.08.2019 р. № 0897. Офіційний сайт Верховної Ради України. https://w1.c1.rada.gov.ua/pls/zweb2/webproc4_1?pf3511=66329
} 
the Bill or Draft Law № 2351 of 30.10 .2019 does not take into account the European standards dealing with the use of animals for experimental research purposes, and does not propose any change to the current legislation of Ukraine.

In the Draft Law № 2351 of 30.10.2019, several critical terms like "laboratory animal", "animal cruelty", etc., are not clarified. Currently, the definition of the term "animal cruelty" given in the Draft Law does not have direct action. It is a replication of the provisions of article 18 of the Law of Ukraine № 3447-IV of 21.02.2006 "On Protection of Animals from Cruel Treatment", which prohibits mistreatment of animals, brutality, beating, genetic modifications of animals, and use of animal for pharmacological and mechanical doping. Therefore, the proposed changes in the definitions are not justified. However, a specified definition embodied in the $11^{\text {th }}$ paragraph of article 1 of the Law of Ukraine ${ }^{12}$ № 3447-IV of 21.02.2006 "On Protection of Animals from Cruel Treatment" can be added: "animal abuse is cruelty to animals, ... except work with experimental animals for scientific purposes, in accordance with the legislation requirements.". A similar change should also be made in the proposed contents of article 89: "cruelty to animals, other violations of the rules of treatment of animals". This phrase pertains to the code of Ukraine on administrative offences. $^{13}$

As mentioned above, the Draft Law № 2351 of 30.10 .2019 does not incorporate the proposed amendments to the Article 26 of the Law of Ukraine № 3447-IV of 21.02.2006 "On Protection of Animals from Cruel Treatment". At the same time, Article 17 of the adopted Draft Law, which establishes an exhaustive list of grounds for killing the animals, does not correlate with Article 26 of the Law of Ukraine № 3447-IV of 21.02.2006 "On Protection of Animals from Cruel Treatment". It also does not embody such grounds as "non-viability of experimental animals". Notably, such an animal, in accordance with current legislation, is subject to killing before suffering; therefore, other grounds for killing an experimental animal are not relevant. Considering the above, it is proposed to supplement Article 17 of the Draft Law № 2351 of 30.10.2019 with the following content: "Killing of animals is allowed.... in case of non-viability of the experimental animal". The Draft Law № 2351 of 30.10 .2019 also does not contain provisions that can be implemented through the rules under the national legislation of Ukraine, and such provisions may relate to: 1) the European Convention for the Protection of Vertebrate Animals used for Experimental and Other Scientific Purposes, $1986^{14}$; 2) European Commission Recommendation 2007/526/EC in respect of premises and care for animals used for experimental and other scientific purposes; 3) EU Directive 2010/63/EU on the protection of animals used for scientific purposes.

Among other things, the principles of replacement, reduction and refinement, which are directly related to the use of animals for scientific purposes (Russell and Burch, 1959), and the ethical component of such actions, need to be implemented as approved by the World Health Organization in 1984 (Norman, 1985).

\footnotetext{
${ }^{12}$ Bulletin of the Verkhovna Rada of Ukraine, 2006, № 27, Article 230

${ }^{13}$ Information of the Verkhovna Rada of UkrSSR, 1984, Annex to No. 51, Article 1122

14 Проект Закону про внесення змін до деяких законів України, які регулюють відносини, пов'язані 3 одержанням документів дозвільного характеру від 29.08.2019 р. № 0897. Офіційний сайт Верховної Ради України. https://w1.c1.rada.gov.ua/pls/zweb2/webproc4_1?pf3511=66329
} 
The strategic reform of the current legislation of Ukraine concerning protection of fauna and flora is necessary. Ukraine ratified in 1986 the European Convention for the Protection of Vertebrate Animals used for Experimental and Other Scientific Purposes. ${ }^{15}$ Hence, the Draft Law № 2351 of 30.10.2019, in accordance with ongoing amendments to certain legislative acts of Ukraine to adopt provisions of certain international agreements and EU directives concerning protection of flora and fauna, must correspond to the aforementioned Convention of the European Union ratified by Ukraine in 1986. The amendments to the Draft Law will accelerate the implementation of international obligations of Ukraine for the protection of animals used for scientific research.

\section{Conclusion}

Animal welfare is not a new subject regulated in most developed countries. It is a manifestation of sophisticated consumerism and citizens' influence demanding ethical treatment of animals. Increasing international trade creates more space for the welfare of animals at the places of their origin, particularly in the countries seeking to strengthen trade and cooperation with Europe. Consequently, today there is a growing awareness worldwide about animal welfare, and a growing demand to increase protection given to animals being used in economic, scientific and experimental projects. Resultantly, in the European Union, the European Parliament and the European Commission, experts and the public have taken steps to consolidate the European Union's leadership to reform the use of animals in scientific research.

In recent years, the international community has increased its response to environmental challenges. One of the most effective solutions to environmental problems is the signing of multilateral instruments and the intensification of international partnerships. Today we can talk about the greening of international cooperation and public policies, which eventually affect all spheres of public life. As part of the process of integration with European Union, Ukraine has an important task, viz. the creation of effective legislation by taking into account the positive experiences of economically and environmentally developed the EU member States. On the one hand, when adopting regulations aimed at implementing radical legal reforms, public authorities must also take into account the national characteristics and legal traditions of the State, whereas, on the other hand, the experiences of other countries in solving similar problems need to be considered. Moreover, the role and importance of comparative legal studies regarding animal protection and welfare have increased recently.

The present study of laws of the EU and Ukraine focusing on cruelty to animals and their use for scientific purposes has shown that implementation of international standards and compliance is very poor and is not supported by an effective mechanism ensuring implementation of the reformed national legislation. On the contrary, the EU Directive 2010/63/EU has shown most effective results through ensuring the welfare of animals. It gave this issue a new civilizational facet. Though the European Union cannot be considered totally free from the use of animals for scientific or economic activities, stringent criteria for granting permission for such use of animals is proved to be a critical factor in effective implementation of international legal instruments.

\footnotetext{
${ }^{15}$ European convention for the protection of vertebrate animals used for experimental and other scientific purposes. Council of Europe, Strasbourg, 1986. 53 p.
} 
The current reformation of legislation of Ukraine, inter alia, is aimed at ensuring the implementation of international standards and compliance pertaining to protection of animals and minimizing their use in scientific and economic activities. However, a satisfactory progress is not recorded to implement international legal obligations of Ukraine. The Draft Law № 2351 of 30.10.2019 is of particular relevance given the complex changes required in the legislation of Ukraine and integration of international experiences creating standards for detention and treatment of animals being used for scientific research. The comments and suggestions given by the authors of this paper in their analysis should be taken into account timely to improve the environmental law of Ukraine; also, the relevant European best practices need to be assimilated.

\section{References}

Bout, H.J., Fentener van Vlissingen, J.M. and Karssing, E.D. (2014). Evaluating the ethical acceptability of animal research. Lab Anim, 43: 411-414.

Bulikina, T. (2019). International legal standards in the field of animal protection and their application in Ukraine. Entrepreneurship, Economy and Law, 11:170-173. URL: http://pgpjournal.kiev.ua/archive/2019/11/29.pdf (Last accessed: 01.04.2020) [in Ukrainian].

Hetman, A.P. (2017). Prospects for the development of environmental legislation in the context of European integration. The current state and prospects of the development of environmental, land and agrarian law in the conditions of European integration: Materials of the round table (8 December 2017, Kharkiv). Kharkiv: Law, 21-33. p. 22. [in Ukrainian].

Kalmykov, D.O. (2013). Prospects for improvement of regulatory legislation regarding the protection of animals from ill-treatment. Forum prava, 1: 367-378. [in Ukrainian].

Lindl, T., Gross, U., Ruhdel, I., von Aulock, S. and Volkel, M. (2012). Guidance on determining indispensability and balancing potential benefits of animal experiments with costs the animals with specific consideration of the EU Directive 2010/63/EU. ALTEX, 29: 219-228.

Lozo, V.I. (2018). Legal Bases of the Ecological Strategy of the European Union (Concept, software, systematization and commentary of the current EU legislation). Kharkiv: Law, p.368 [in Ukrainian].

NHMRC (2013). Australian code for the care and use of animals for scientific purposes, 8th edition. Canberra, Australia: National Health and Medical Research Council (NHMRC). Online: https://www.nhmrc.gov.au/about-us/publications/australian-code-care-and-useanimals-scientific-purposes\#block-views-block-file-attachments-content-block-1

Norman H.J. (1985). CIOMS ethical code for experiments involving animals. WHO Chronicles, 39(3): 3-9.

Olsson, A., Varga, O. and Sandoe, P. (2015). A matter of importance: considering benefit in animal ethics review. ALTEX Pro, 4: 33-36.

Russell, W.M.S. and Burch, R.L. (1959). The Principles of Humane Experimental Technique. London: Methuen, ISBN 0900767782. 238 p.

Sandoe, P., Franco, N.H., Lund, T.B., Weary, D.M. and Olsson, A. (2015). Harms to animals - can we agree on how best to limit them? ALTEX Proc, 4: 28-32.

Voelkl, B., Altman, N.S., Forsman, A., Forstmeier, W., Gurevitch, J., Jaric, I., Karp, N.A., Kas, M.J., Schielzeth, H., Van de Casteele, T. and Würbel, H. (2020). Reproducibility of animal research in light of biological variation. Nature Reviews Neuroscience, 2020. Doi: 10.1038/s41583-020-0313-3. 